\title{
Analysis of Modality System in English Advertising Slogans
}

\author{
Weixuan $\mathrm{Shi}^{1}$, Wenqian $\mathrm{Li}^{2 *}$ \\ ${ }^{1}$ Professor in School of Foreign Languages, North China Electric Power University, NO 689 Road, North District, Baoding, Hebei, China \\ ${ }^{2}$ Graduate Student in School of Foreign Languages, North China Electric Power University, NO 689 Road, North District, Baoding, Hebei, China
}

DOI: $10.36348 /$ sijll.2020.v03i10.001

| Received: 03.10.2020 | Accepted: 14.10.2020 | Published: 18.10 .2020

*Corresponding author: Wenqian Li

\section{Abstract}

It is distinctive that English advertising slogans feature in unique and discourse characteristics. On the ground of modality system in interpersonal meta-function, about 120 pieces of English slogans with modality are randomly selected as samples from 500 famous advertisements. These slogans are systematically analyzed from the perspective of modality type, modal value and modal responsibility, aiming at interpreting the functional characteristics of English slogans. The result is that English slogans usually employ modalization, with median or low modality value, accompanied by expressive subjective orientation. It is anticipated that this article can render guides for advertisers to compose advertising slogans effectively and enhance the ability of advertising speech communication.

Keywords: English advertising slogans, modality, interpersonal meta-function.

Copyright ( $) 2020$ The Author(s): This is an open-access article distributed under the terms of the Creative Commons Attribution 4.0 International License (CC BY-NC 4.0) which permits unrestricted use, distribution, and reproduction in any medium for non-commercial use provided the original author and source are credited.

\section{INTRODUCTION}

With the economy globalization and the unremitting development of society, advertising as a mode of disseminating information has penetrated people's daily life inch by inch and thus becomes an indispensable portion of people's life. The market competition at present is piled up increasingly, and the commercial advertising is one of the crucial means to compete for the market. The English advertising slogans, viewed from the discourse function, possess their own vocabulary, syntax, lexeme, stylistic style and textual features. Its paramount purpose is to publicize products, to spread the information of products, and to guide or summon people to unconsciously engage in purchasing. Therefore, in order to achieve its purpose, advertisers are desperately meticulous in the choice of words and phrases, using unique and distinct means of expression.

Leech [1] initiated to explore the stylistic features of English advertising discourse from the perspective of stylistics. From then on, the research concerning advertising has not been suspended. Later, Halliday [2] conceived that the construction of functional grammar can provide a theoretical basis for discourse analysis, including both oral discourse and written discourse in English, and he proposed three meta-functions (ideational meta-function, interpersonal meta-function, and textual meta-function).
Hence, this article comprehensively analyzes English advertising slogans from the modality system in interpersonal meta-function, aiming at interpreting the functional characteristics of English slogans. By investigating how advertising achieves its purpose through the modality, it does instruct advertisers to compose advertising slogans effectively, which can better meet the functions of advertising and enhance the ability of advertising speech communication.

\section{LITERATURE REVIEW}

Interpersonal meta-function, as one of the three meta-functions in functional grammar, not only refers to people using language to communicate with others, establishing and maintaining interpersonal relationships, influencing others' behavior, but also means using language to express the world view [3].

As a part of interpersonal meta-function, the modality system is indispensable to express interpersonal meaning. Modality is the expression of the speaker's attitude about the certainty, likelihood or frequency of something happening or being. Modality, to a large degree, is a semantic category operating at the sentence level but having effects on the whole text. According to Halliday, modality is the presentation of the standing point of the speaker either "on validity of the assertion or on the rights and wrongs of the proposal" [3]. This definition seems to accord with 
Lyons, "Modality is concerned with the 'opinion and attitude' of the speaker".

Halliday [2] divided the modality system into two types: modalization and modulation, and he attached three modality values: high, median and low.

Modalization refers to any degree of probability (maybe, could, must) and any intermediate degree of usuality (sometimes, usually, always). Probability and usuality can be realized in the finite modal auxiliary in a verbal group or with modal adjuncts like probably or usually or both. The use of modality always indicates doubt to some degree, at least more uncertainty than not using any expression of modality at all.

Modulation refers to degrees of obligation and inclination in proposals (offers and commands). In the exchange of goods and services, the default form is the imperative. Accordingly, modality here is concerned with the amount of obligation or willingness, readiness to do or give. And we can realize modulation of obligation and inclination in orders and offers through the uses of modal auxiliaries.

Obviously, advertising discourse is a relatively practical genre, whose primary function is to establish a relationship between advertisers and consumers. It is necessary to investigate the interpersonal metafunction. In the past few decades, many linguists have penetrated into advertising discourse from various angles.

For instance, diverse hierarchical levels of advertising are explored profoundly from the perspective of stylistics [1, 4, 5]. A part of pragmatic linguists focuses on the application of English advertising [6], and the discourse analysis of advertising [7]. Most scholars [8-11] study the rhetoric of advertising from the three levels of language, namely phonetics, lexical, and syntax. From the perspective of functional grammar, a number of researches center on the mood system [12-14].

There are few studies based on the modality system of English advertising, in which most of them are qualitative researches. Inevitably, quantitative studies in this field are insufficient. The latest quantitative research is carried out by $\mathrm{Yu}$ and Yanlong [15], who employed the mood and modality system to analyze the linguistic features of six Chinese advertising discourses.

Therefore, in order to make up for the vacancy of researches in the area, this article applies quantitative method to analyze modality system in English advertising slogans, which has important practical significance.

\section{ANALYSIS OF MODALITY SYSTEM IN ENGLISH ADVERTISING SLOGANS}

To accomplish the quantitative analysis, the data is from about 120 pieces of English slogans with modality randomly selected from 500 famous advertisements (https://wenku.baidu.com) by the random sampling function of excel. These slogans are systematically analyzed from the perspective of modality type, modal value and modal responsibility, targeting at interpreting the frequency of occurrence of various aspects of the modal system.

\section{Modalization and Modulation}

By means of modality system, the speaker masterly integrates the topic theme, stance, the correctness and validity of the conclusion. According to the functional grammar, the modality system consists of two parts: modalization and modulation. The former is the speaker's judgment on the probability and the usuality of a discourse proposition, while the latter is the judgment on the obligation and inclination of a discourse proposition.

By analyzing the selected examples at length, the statistical table can be drawn as follows:

Table-1

\begin{tabular}{|c|c|c|c|}
\hline \multicolumn{2}{|c|}{ Description } & Number & Percentage \\
\hline Modalization & Probability & 66 & $55.00 \%$ \\
\cline { 2 - 4 } & Usuality & 36 & $30.00 \%$ \\
\hline \multirow{2}{*}{ Modulation } & Obligation & 4 & $3.33 \%$ \\
\cline { 2 - 4 } & Inclination & 14 & $11.67 \%$ \\
\hline
\end{tabular}

What can be apparently discovered from the Table-1 is that the type of modality mostly applied in English slogans is the modalization, in which most modal verbs tend to present probability. The modulation is denoted much less in English slogans, while it still exerts its functions to some extent.

\section{Modalization}

The modality is chiefly expressed by modal verbs such as "will, should, would, could, can, must" or modal adverbs such as "probably, usually, possibly, always, certainly", etc. In addition, these two forms can also be combined together to achieve the denotation of modalization.

Table-2

\begin{tabular}{|c|c|c|c|}
\hline \multicolumn{2}{|c|}{ Description } & Number & Percentage \\
\hline \multirow{2}{*}{ Modalization } & Modal Verbs & 79 & $77.45 \%$ \\
\cline { 2 - 4 } & Modal Adverbs & 23 & $22.55 \%$ \\
\hline
\end{tabular}

From the Table-2, it can be found that modal verbs in modalization are used frequently in English slogans, accounting for 77.45 percent overall.

Modal verbs in English not only have plain meanings (such as "can" usually expresses ability or competence; "may" indicates permission, etc.), in a 
particular genre they also exert disparate functions due to their pragmatic ambiguity. In English advertising, on the one hand, advertising creators attempt to manifest their objective stance through modal verbs, that is, they are only information givers, do not interfere with consumers' freedom of making choice. On the other hand, they must embody the persuasion functions of advertising discourse, which is to reflect the credibility of its message as much as possible; consequently, consumers can recognize and adopt the advertising products. Therefore, modal verbs are one of the most common ways to reflect the interpersonal meaning of advertising discourse.

For example,

(1) You can't beat a Sealy good night's sleep. (Sealy beds)

(2) Look, you can't hide Mackintosh. (Mackintosh, a kind of jewelry)

In the case of (1), the advertisers implied by "can't" that there seems to be no other bed in the world, only "Sealy" is the most comfortable for consumers. Accordingly, they have no alternatives but to purchase the product.

Example (2) directly conveys the advertiser's intention to the consumer through "can't". Seemingly, the product "Mackintosh" is desperately credible; as a result, the jewelry must be displayed to accept praise or jealousy. Apart from it, advertisers stimulate or urge consumers to take actions, trying and purchasing the product in person.

Modal adverbs also appear in the English slogans, accounting for 22.25 percent.

(3) Does Smoking Really Make You Look More Grown Up? (Reynolds American)

In the case of (3), the interpersonal relationship between the tobacco company and the potential young smoker is established through the use of the modal adverb "really". On the basis of the modality, the advertisers expressed their opinions, attitudes and even confidence towards their own products. From this technique of modalization, advertising is deemed as the way to achieve the goal of promoting products and services by guiding potential consumers.

\section{Modulation}

\section{Table-3}

\begin{tabular}{|c|c|c|c|}
\hline \multicolumn{2}{|c|}{ Description } & Number & Percentage \\
\hline Modulation & Modal Verbs & 14 & $100 \%$ \\
\cline { 2 - 4 } & $\begin{array}{c}\text { Extension of } \\
\text { Predicate }\end{array}$ & 0 & 0 \\
\cline { 2 - 4 } & Others & 0 & 0 \\
\hline
\end{tabular}

The manifestation of modulation is mainly achieved by modal verbs (such as "will should, must, etc.") and extensions of predicates (such as "allowed to do, supposed to do, required to do, etc.") [2]. In addition, other parts of speech (such as verbs, nouns) and prepositional phrases can also reveal the modality [16]. However, in English advertising slogans, only modal verbs exist in modulation.

(4) You'll never put a better bit of butter on your knife. (Country Life butter)

(5) We'll leave the light on for you. (Motel 6)

(6) Don't consume it or it will consume you. (Stop smoking ad)

Modulation is the judgment of the speaker on the obligations and willingness of a discourse proposition. In the slogans collected, modal verbs like "will" appear frequently. Advertisers often make promises to potential consumers and guarantee product quality by means of modulation.

It also can be found that there are fewer modal auxiliaries in the English advertising slogans, such as "must", "should". This is because advertisers have no right to order potential consumers, and such orders will violate the consumer's right to make choice freely. Therefore, advertisers often use modal expressions expressing willingness in their evaluation of products to improve their position in the dialogue with consumers.

\section{Modal values}

Different modal verbs in English generally indicate different levels of modality [2]. Halliday [2] divided modal verbs into three levels, low modal value (may, might, can, could...), median modal value (will, would, shall, should...) and high modal value (must, ought to, have to, need...). While exploring the interpersonal meaning in the slogan, different modal words can reflect the subtle relationship between the communicative parties.

Table-4

\begin{tabular}{|c|c|c|c|}
\hline \multicolumn{2}{|c|}{ Description } & Number & Percentage \\
\hline Modalization & HIGH & 8 & $6.67 \%$ \\
\cline { 2 - 4 } & MEDIAN & 38 & $31.67 \%$ \\
\cline { 2 - 4 } & LOW & 56 & $46.67 \%$ \\
\hline Modulation & HIGH & 2 & $1.67 \%$ \\
\cline { 2 - 4 } & MEDIAN & 5 & $4.17 \%$ \\
\cline { 2 - 4 } & LOW & 11 & $7.17 \%$ \\
\hline
\end{tabular}

From the Table-4, the words are very good at using various modal words, and generally low-media modal words are commonly used.

(7) How can a magazine be strong regionally if it is not strong locally? (Asian Weekly)

(8) Carlsberg: the best beer in the world is probably the best beer in the world (Carlsberg)

(9) Will life take you? Where will life lead you? (Louis Vuitton)

The application of modal words can showcase the reliability and authenticity of information sources. 
Example (7) and (8) both use low modal value words, indicating that the advertisers consciously reduce their social status to win the customers trust and good impression. It shows respect for customers and fully reflects the concept: client is the God, quality is life, honest is essence, credit standing is the prime thing. However, in example (9), the appropriate use of the median and high value modal word "will" unfolds the advertiser's confidence in their products for further promoting. There is no doubt that "will" shows the equal relationship between the advertiser and the customer and shows how the advertiser achieves its goal of persuading the customer step by step.

It appears that English advertising slogans generally contain low modal value words from the Table-4, from which advertisers can avert from being blamed for the authenticity of the advertisement. In this way, the accuracy of the advertisement is advanced considerably. In the eyes of customers, they will feel that they can objectively understand the quality and performance of the products and they will give more trust to the product. Furthermore, personal interest is also well respected as a matter of fact, owing to the fact that these kinds of slogans leave behind right of choice to customers.

Through analysis, it also can be discovered that there are many slogans using median modal value word, such as "will" and"should", suggesting what is going to happen, and the information provided is merely accordance with customers' beliefs, predictions or intentions, not facts. What' more, "will" bears with the attitude of overt commitment.

(10) If you have oily skin, our popular Daily Oil Control will help keep your skin balanced so it looks radiant instead of oily.

In the above example, "will" expresses a psychological process. Potential customers want to keep their health, and the word will throw customers light on the effects in using the product.

\section{Modal Responsibility}

The modality can be divided into four types: explicit subjective, explicit objective, implicit subjective and implicit objective.

The orientation of explicit subjective clearly expresses the speaker's own views, attitudes, or comments about certain propositions, not facts. The implicit subjective makes these personal performances less obvious, so its proposition is more like a fact than a speaker's point of view. The explicit objective is achieved mainly through modal qualifiers. Implicit objective tendency is realized by verb passive form.
Table-5

\begin{tabular}{|c|c|c|}
\hline Description & Number & Percentage \\
\hline Explicit Subjective & 3 & $2.50 \%$ \\
\hline Explicit Objective & 17 & $14.17 \%$ \\
\hline Implicit Subjective & 69 & $57.50 \%$ \\
\hline Implicit Objective & 31 & $25.83 \%$ \\
\hline
\end{tabular}

From the data, it can be found that most of the English slogans are inclined to express implicit subjective modal meaning, and most of implicit subjective modalities implemented are through positive affirmative words or negation modal qualifiers, whereas there are little modalities through evaluation adjuncts.

(11) Your skin should glow, not shine! If you have oily skin, our popular Daily Oil Control will help keep your skin balanced so it looks radiant instead of oily.

(12) The all - in X that won't limit your advertising ability

(13) Is your microwave cooking fast? You bet!

"Bet" makes the slogan more determined in tone, so the consumer will make sure that his microwave oven is heating very quickly. From the above comparative analysis, English advertising has the tendency to use more subtle subjective modality, thus making advertisements more like presenting facts and leaving choices to potential customers rather than imposing ideas on them.

\section{Conclusion}

Based on the systemic functional grammar, this article analyzes the modality system of English advertising slogans. Through the data analysis of 120 pieces of slogans and examples, it can be concluded that English slogans usually employ modalization, with median or low modality value, accompanied by expressive subjective orientation. The tactfully use of this system enables the interpersonal function of advertising to play a considerable role in advertising discourse. Flexibly choosing and considering appropriate modal words to convey product information and attract potential consumers is an issue that advertisers are required to ponder over. The purpose of advertising is to promote products and services so that the relationship between advertisers and consumers can be established. Therefore, from the perspective of functional grammar, the modality system is particularly prominent in advertising discourse to convey the interpersonal meaning.

\section{REFERENCES}

1. Leech, G. (1966). English in Advertising. London: Longman.

2. Halliday, M. A. K. (2000). An Introduction to Functional Grammar. $2^{\text {nd }}$ ed. London: Edward Arnold.

3. Bloor, T., \& Bloor, M. (2001). The Functional Analysis of English: A Hallidayan Approach. 
Beijing: Foreign Language Teaching and Research Press.

4. Guowen, H. (2001). Theory and Practice of Discourse Analysis-A Study of Advertising Discourses. Shanghai: Shanghai Foreign Language Education Publishing.

5. Xiubai, Q. (2002). English Style Summary. Shanghai: Shanghai Foreign Language Education Press.

6. Bihao, Z. (2012). A Study of Presuppositions in Chinese and English Advertising Discourses. Shanghai International Studies University.

7. Wangqi, J. (2011). Research on Discourse Linguistics. Beijing: Peking University Press.

8. Jun, D. (1998). Rhetorical Features of English Advertising Headlines. Chinese Science and Technology Translation, (4):44-46.

9. Russell, M. (1992). A Preliminary Study of the Figure of Speech in Advertising English (Part One). Modern Foreign Languages, (4):55-59.

10. Russell, M. (1993). A Preliminary Study of the Figure of Speech in Advertising English (Part Two). Modern Foreign Languages, (1):50-54.
11. Bing, X., \& Yue'e, L. (2000). Pragmatics and Aesthetics of Advertising Puns. Foreign Languages and Foreign Language Teaching, (6):35-36.

12. Hongtao, Z. (2009). Interpersonal Functions of Mood in English Advertising Discourse. Shandong Foreign Language Teaching, (2):101105.

13. Yili, W. (2007). A Systematic Analysis of Mood and Attitude in English Advertising Discourses. Harbin Engineering University.

14. Yanqing, F. (2019). Interpersonal Meaning of Mood System in English PSA Discourses. Xiamen University.

15. Yu, L., \& Yanlong, F. (2017). The Interpersonal Meaning of Advertising Discourse from the Perspective of Systemic Functional Grammar. Sino-US English Teaching, (1): 40-45.

16. Hongyang, W., \& Chunsong, C. (2011). Contrastive Study of Modality in English Political Speeches and Academic Speeches. Studies in Electronic Education, (5): 21-24. 